\title{
Validation of Career Planning Guidebook for College Students
}

\author{
Dian Kinayung', Difa Ardiyanti', Muhammad Hidayat ${ }^{3}$ \\ 1,2,3Faculty of Psychology, Universitas Ahmad Dahlan
}

Submitted 30 November 2018 Accepted 30 January 2020 Published 24 August 2020

\begin{abstract}
Career exploration is one of the career development tasks that individuals commonly go through. In reality, these activities may cause problems for specific individuals, including students. Career guidance can assist individuals in successfully passing through this stage of a person's life. Of the many career intervention models available, no previous research has utilized career planning guidebooks as a form of intervention to help students make career plans. This study aimed to validate a career planning guidebook created by the researcher and test its content and functional validity. Tests of content validity were conducted through professional judgment, while tests of functional validity were conducted via a quasi-experiment. The results showed that all the contents of the career planning guidebook were aligned with the goals of the career planning guidebook (Average of $\mathrm{V}=0.6$ ). The experiment results indicated significant difference in perceptions of career planning before and after the intervention $(Z=-3.987$; $\mathrm{p}=0.000)$. The findings concluded that the career planning guidebook is valid, both in terms of content and function.
\end{abstract}

Keywords: career intervention; career planning; career planning guidebook; content validity; validation

According to Super's (1980) career development stages, 18-21-year-old adolescents are at the exploration stage of their career development, specifically the sub-phase of crystallization of preference. University students (who are aged 18 to 21) are included within this group. According to Super (1980), this stage is marked by an exploration of various types of information and career opportunities that meet a person's interest. In the crystallization phase, individuals make choices on a more specific career field. For example, they choose to go into the workforce directly or may decide to pursue an undergraduate degree upon

Address for correspondence:

difa.ardiyanti@psy.uad.ac.id graduating from high school. They may also choose a specific program for their undergraduate degree, or choose a specific job. These explanations indicate that exploring and making career choices are an essential part of an individual's career development.

In reality, career exploration is associated with different types of problems among individuals, including students. Talib, Mohamad, and Wahab (2015) suggested that students often experience the following career problems: (1) lack of perspective on future planning, (2) doubts in making career choices, (3) lack of knowledge on how to look for work, and (4) worry of being unemployed. Also, Yollanda (2017) found that final year 
students often experienced problems of confusion regarding their future caused by their lack of knowledge on career opportunities. Talib, Salleh, Amat, Ghavifekr, and Ariff (2014) found that university graduates often had insufficient competence in seeking work opportunities, exhibit low confidence, unable to make effective decisions, and did not make any career plans.

Jaffe and Scott (1991) further elaborated that exploration of career opportunities, making career plans, and making career choices are essential parts of career planning. This indicates that the career problem experienced by students (Talib et al., 2015; Talib et al., 2014; Yollanda, 2017) are related with their abilities in making career plans. Successfully passing the career developmental stage depends on the students' ability to make career plans effectively. Consistent with this reasoning, Prascova, Creed and Hood (2015) showed that individuals with proper career planning had low career-related stress.

Career planning is a process that moves toward career maturity. Hidayat and Alsa (2018) showed that the better the person can plan their career, the better their career maturity. According to Jaffe and Scott (1991), career planning is a gradual process, consisting of 5 stages, namely: (1) self-evaluation, (2) exploring opportunities, (3) making career plans, (4) taking action, and (5) evaluating the results. These are the stages that each person passes when making a good career plan. Ardiyanti and Alsa (2015) found that career planning increases self-efficacy in making career decisions, allowing individuals to increase their confidence in making the correct career decision. High self-efficacy in career decision making reduces the individual's difficulty in making career decisions (Iffah, 2012;
Sawitri, 2009). Therefore, the research mentioned above all suggested that career planning plays a vital role in career-related decisions.

Germeijs and Verschueren (2007) found that faulty career decision making would lead to psychological, academic, and relational problems. Thus, it is essential to make sure that individuals have a good career plan to make the correct career decision. Career counseling, therefore, can play an important role to aid individuals in making career choices. Career counseling influences an individual's ability to make career choices (Teychenne, Parker, Teychenne, Sahlqvist, Macfarlane, \& Costigan, 2019; Chen \& Zhou, 2018; Lam \& Santos, 2017; Hanggara, 2016; Fouad, Cotter, \& Kantamneni, 2009). By having the right assistance, individuals can pass the career exploration stage well and make better career decisions. Career plan interventions can be used to overcome typical career problems experienced by students (Yollanda, 2017; Talib et al., 2015; Talib et al., 2014). Based on a review of the existing research, many models exist in relation to career interventions for example: Individual career counselling (Sangganjanavanich \& Magnuson, 2011), group career counselling (Lestari, 2010), interview (Amundson, Borgen, Iaquinta, \& Butterfield, 2010), group counselling (Hanggara, 2016), courses (Fouad et al., 2009), workshops (Kusumaningrum, 2012), and interventions in the form of training (Hidayat \& Alsa, 2018; Ardiyanti \& Alsa, 2015; Syahraini, 2012; Wang, Zhang, \& Shao, 2010; Kustanani, 2010; Mulyana, 2009). Most of the intervention models involve another person, either as a trainer, facilitator, or a group member. When the intervention commences, either in the form of counselling, training, or work- 
shops, the success of the career planning improvement does not solely rely on the individual but is also affected by group dynamics. The intervention process can be done more intensively with more focus on the individual's needs and situation.

Based on research on the various career intervention models, it appears that group interventions are most common. Individual interventions that have been conducted use the counselling model (Sangganjanavanich \& Magnuson, 2011). This means that individuals still need another person (counsellor) to help, despite students being late adolescents who are capable of making autonomous decisions on their own. Therefore, it is plausible that career planning intervention which involves self-reliance remains an important topic of research to be tested. Unfortunately, our review had shown that no research exists which used career interventions focusing on building student autonomy in planning a career. Therefore, the researcher was interested in creating a guidebook for career planning that can be used as an individual guide for the students. This guidebook is expected to make students self-reliant and no longer needing to depend on others to make their own career plan.

The guidebook was made with reference to the career planning theory proposed by Jaffe and Scott (1991). This books contains material about (1) selfanalysis, (2) career perspectives, (3) making goals and career plans, (4) implementation or plan of action, and (5) evaluation. This book contains comprehensive material about the steps of making career plans, information related to relevant careers, and also includes work sheets to help individuals make career choices. The career plan guidebook was designed as an alternative intervention to enhance knowledge and abilities to improve a person's ability to make better career choices.

In this research, the career plan guidebook was made by testing its content validity and functional validity which can be used by the students or by a lecturer to help students in planning their career. Azwar (2017) mentioned that in the context of validation studies, content validity does not only cover the effectiveness of the intervention, however it also relates with the alignment of content material and the goal of the intervention. Confirmation of the alignment between these two aspects are obtained through expert judgment and ratings on the intervention materials. These ratings would then be analyzed to obtain a content validity coefficient, namely the Aiken's $V$.

Azwar (2017) mentioned that in validation studies, the content validity coefficient describes the relevance of the topics within the intervention module with the goals of the intervention. The validity coefficient is derived from the average of all the $V$ coefficients in each topic. In order to meet logical validity, there also needs to be evaluation toward the psychometric qualities of an intervention module through experimental research. By conducting experiments, we will obtain information of the functional validity of the intervention module. The psychometric parameters will have no meaning whatsoever when it is not based on content validity and vice versa.

Based on Azwar's (2017) suggestions above, the guidebook for career planning needed to be validated because this book takes the form of an intervention. Testing the validity of the career planning guidebook can be seen from its content (content validity) or its psychometric 
properties (functional validity). Through both tests we expected to obtain a more comprehensive research since the validity of the book is not only seen from the alignment between content, intervention goals, and theoretical concepts used but also its effectiveness in producing the outcomes that were expected.

\section{Method}

This study recruited 24 third semester psychology undergraduate students from Universitas Ahmad Dahlan. These students already had one year of study in the faculty and so they should be familiar with the type of knowledge and skills that the faculty is developing. Furthermore, at this stage of their study, there was still time for them to develop their own career plans before graduating. The sample was not taken randomly, however participants voluntarily participated in the experiment. The career planning scale was used to measure career planning perceptions. The career planning scale was tried among 127 students and had a reliability coefficient of 0.928 with a discrimination power ranging from 0.356 to 0.644 . The scale measured five aspects of career planning based on Jaffe and Scott's theory (1991), namely selfunderstanding, explore opportunities, make plans, take action, and evaluate results.

This research was conducted in two stages. The first stage tested the content validity of the career planning guide book. The second stage tested the functional validity of the intervention. Test of content validity was conducted by having experts give their professional judgment towards the content of the guidebook. These experts were asked to evaluate the relevance of the content with the overall goal of the intervention. Based on these expert judgments, a content validity coefficient (Aiken's $V$ ) was obtained as a measure of content validity. Tests toward functional validity was conducted using a quasi-experimental design. The study used a one group pretest and posttest design, whereby the intervention was given to one group of participants and measurement was conducted before and after the experiment (Shadish, Cook, Campbell, 2002). The design of the research can be visualized by Figure 1 .

$$
\mathrm{O}_{1} \quad \mathrm{X} \quad \mathrm{O}_{2}
$$

Figure 1. Research design

Description :

$\mathrm{O}_{1}$ : Career plan score before intervention (pretest)

$\mathrm{O}_{2}$ : Career plan score after intervention (post-test)

X : Manipulation/ Intervention (Career planning guidebook)

The intervention took the form of the career planning guidebook. This guidebook was made based on the theory of career planning by Jaffe and Scott (1991). The guidebook contained the following material: (1) self-analysis, (2) career perspectives, (3) goal setting and career planning, (4) implementation and action plan, and (5) evaluation of results. Worksheets were also provided for each section of the guidebook to assist individuals in understanding the activities of career planning. The intervention was conducted in 5 days.

Using the quasi-experimental design, we hope to observe significant differences between career planning scores of participants in $\mathrm{O}_{1}$ and $\mathrm{O}_{2}$, with higher scores in $\mathrm{O}_{2}$ compared to $\mathrm{O}_{1}$. This would provide evidence of the effectiveness of the intervention/ manipulation, namely the career planning guidebook. This 
would also provide evidence of the functional validity of the intervention. Data analyses was then conducted to test differences between career planning scores between $\mathrm{O}_{1}$ and $\mathrm{O}_{2}$ using the Wilcoxon signed-rank test.

\section{Results}

\section{Content validity}

To test for content validity, three experts in the field of career planning were asked to professionally evaluate the contents of the guidebook. The data collected from this process consisted of both qualitative and quantitative elements. The quantitative element consisted of scores representing the experts' evaluation of the guidebook using Aiken's $V$. A summary of the results of this analyses is presented in Table 1.

Overall, we obtained a $V$ coefficient ranging from 0.5-1 with an average $V$ of 0.6 . Based on Table 1, we could see that aspect 1 (self-understanding), obtained the highest $V$ and aspect 2 (explore opportunities) obtained the lowest $V$ of 0.525. Azwar (2017) suggested that $V$ values higher than 0.50 indicated good content validity, and the average score of all sub-section constitutes the overall content validity for the whole intervention module. Based on Table 1, we can see that the career planning guidebook had good content validity because the total average $V$ coefficient was 0.6.

Table 1.

Summary of Content Validity Tests

\begin{tabular}{|c|c|c|c|}
\hline $\begin{array}{l}\text { Sub-section } \\
\text { (aspects) }\end{array}$ & Goal & Activities/Material & $\begin{array}{c}\text { Aiken's } \\
\text { V }\end{array}$ \\
\hline \multirow{5}{*}{$\begin{array}{c}\text { Self- } \\
\text { understanding }\end{array}$} & $\begin{array}{l}\text { a. Able to identify } \\
\text { personal strengths } \\
\text { and weaknesses }\end{array}$ & $\begin{array}{l}\text { 1. Read explanations about self- } \\
\text { understanding from the guidebook. Work } \\
\text { on activity } 1 \text { on creating a mind map of the } \\
\text { self and work on activity } 2 \text { about SWOT }\end{array}$ & 1 \\
\hline & $\begin{array}{l}\text { b. Know the jobs that } \\
\text { are of interest }\end{array}$ & $\begin{array}{l}\text { 2. Read material about exploring } \\
\text { opportunities and gathering information } \\
\text { from the internet or ask relevant people } \\
\text { (lecturer, alumni etc.) }\end{array}$ & 0.5 \\
\hline & $\begin{array}{l}\text { c. Understand } \\
\text { personal } \\
\text { characteristics }\end{array}$ & $\begin{array}{l}\text { 3. Read material about understanding the } \\
\text { self and work on Activity } 1 \text { about making } \\
\text { a mind map of the self. Work on activity } 2 \\
\text { about SWOT }\end{array}$ & 0.6 \\
\hline & $\begin{array}{l}\text { d. Understand } \\
\text { personal } \\
\text { ambitions/dreams }\end{array}$ & $\begin{array}{l}\text { 4. Read material about self-understanding } \\
\text { and work on Activity } 1 \text { about making a } \\
\text { mind map of the self. Work on Activity } 4 \\
\text { about Plan A \& Plan B }\end{array}$ & 0.6 \\
\hline & & Average & 0.675 \\
\hline
\end{tabular}




\begin{tabular}{|c|c|c|c|}
\hline $\begin{array}{l}\text { Sub-section } \\
\text { (aspects) }\end{array}$ & Goal & Activities/Material & $\begin{array}{l}\text { Aiken's } \\
\text { V }\end{array}$ \\
\hline \multirow[t]{3}{*}{$\begin{array}{c}\text { Explore } \\
\text { opportunities }\end{array}$} & $\begin{array}{l}\text { a. Seek information on } \\
\text { career opportunities }\end{array}$ & $\begin{array}{l}\text { 1. Read material on exploring opportuni- } \\
\text { ties, explore career opportunities using } \\
\text { the internet or ask a relevant person } \\
\text { (lecturer, alumni etc.). Work on Activity } \\
3 \text { on the } 5 \text { professions in highest demand }\end{array}$ & 0.5 \\
\hline & $\begin{array}{l}\text { b. Prepare self for } \\
\text { alternative careers }\end{array}$ & $\begin{array}{l}\text { 2. Read material about making a career } \\
\text { plan. Work on Activity } 4 \text { about Plan A } \\
\text { and Plan B }\end{array}$ & 0.55 \\
\hline & & Average & 0.525 \\
\hline \multirow{4}{*}{ Make plans } & $\begin{array}{l}\text { a. Able to set goals or } \\
\text { targets of behavioral } \\
\text { change to achieve the } \\
\text { desired career. }\end{array}$ & $\begin{array}{l}\text { 1. Read material about making a career } \\
\text { plan. Work on Activity } 4 \text { about Plan A } \\
\text { and B }\end{array}$ & 0.6 \\
\hline & $\begin{array}{l}\text { b. Able to prepare } \\
\text { alternative solutions } \\
\text { as a consequence of } \\
\text { goal setting }\end{array}$ & $\begin{array}{l}\text { 2. Read material about career planning. } \\
\text { Work on Activity } 4 \text { about Plan A and B }\end{array}$ & 0.55 \\
\hline & $\begin{array}{l}\text { c. Create a career plan to } \\
\text { achieve goals }\end{array}$ & $\begin{array}{l}\text { 3. Read material about creating a career } \\
\text { plan. Work on Activity } 4 \text { about Plan A } \\
\text { and Plan B }\end{array}$ & 0.6 \\
\hline & & Average & 0.583 \\
\hline \multirow{3}{*}{ Action } & $\begin{array}{l}\text { a. Know what is needed } \\
\text { to achieve the goals }\end{array}$ & $\begin{array}{l}\text { 1. Read material about implementation. } \\
\text { Work on Activity } 5\end{array}$ & 0.6 \\
\hline & $\begin{array}{l}\text { b. Able to create an } \\
\text { activity schedule }\end{array}$ & $\begin{array}{l}\text { 2. Read material about implementation and } \\
\text { work on Activity } 6\end{array}$ & 0.55 \\
\hline & & Average & 0.575 \\
\hline \multirow{4}{*}{ Evaluation } & $\begin{array}{l}\text { a. Able to evaluate the } \\
\text { goals that were set }\end{array}$ & $\begin{array}{l}\text { 1. Read material about evaluating } \\
\text { outcomes. Work on Activity } 7\end{array}$ & 0.6 \\
\hline & $\begin{array}{l}\text { b. Able to evaluate the } \\
\text { plan of action }\end{array}$ & $\begin{array}{l}\text { 2. Read material about evaluating } \\
\text { outcomes. Work on Activity } 7\end{array}$ & 0.6 \\
\hline & & Average & 0.6 \\
\hline & & Average $\mathrm{V}$ (total) & 0.6 \\
\hline
\end{tabular}

\section{Functional validity}

Tests of functional validity was conducted using a quasi-experimental approach with the one group pretest and post-test design. The experiment was conducted to test the effectiveness of the guidebook in increasing a person's ability in career planning. The results of the experiment was analyzed using the Wilcoxon signed- rank test. The results of the analyses showed a $Z=-3.987, p=0.000(p<0.01)$ which means that there was a difference of career planning perceptions before and after engagement with the guidebook. Increases in scores of career planning before and after the intervention on the experiment group can be observed in Figure 2 . 


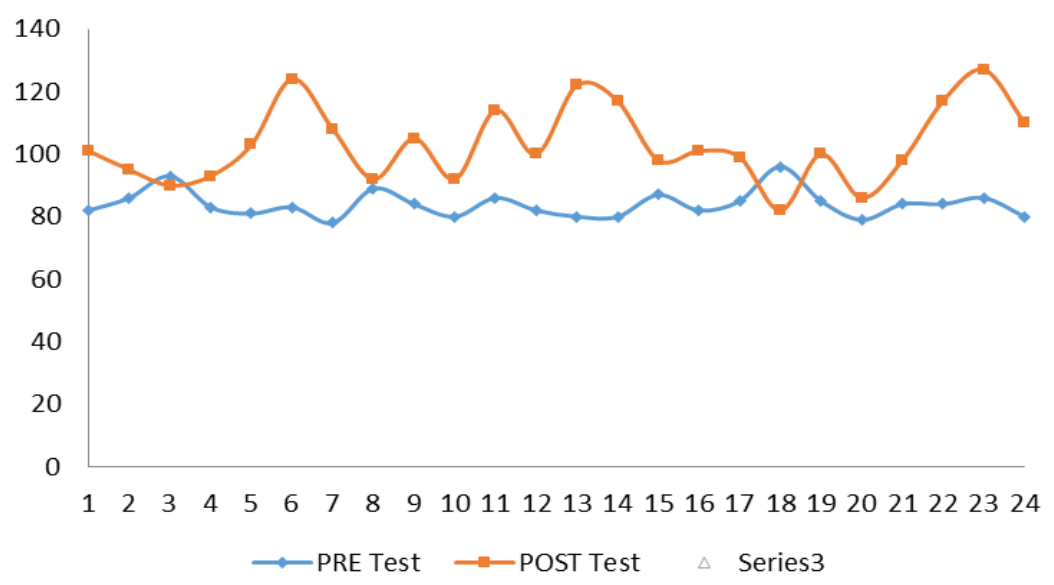

Figure 2. Increases in career planning scores before and after the intervention in the experimental group

Before working on the career planning guidebook, the average career planning score of the subjects was 83.96. Following the intervention, the scores increased to 103.08. This showed that the intervention was able to improve the subjects' ability in career planning. Subjects felt that they were better able to plan and choose a career after reading the career planning guidebook.

\section{Discussion}

The guidebook used in this study as an intervention to improve students' career planning abilities was shown to be valid. Content validity was established through professional judgment, and functional validity was established using a quasiexperimental approach. Based on the content validity tests (Table 1 ), we could see that all aspects of the guidebook had good content validity. However, aspect 2 (explore opportunities) needed further improvement to increase its $\mathrm{V}$ coefficient. Concerning the qualitative aspects of the expert evaluation, one evaluator suggested giving an example of the career opportunities available in psychology, especially if it targeted first-semester students. This is because first semester students would not have sufficient knowledge about the available career opportunities in psychology.

Overall, the career planning guidebook had a content validity coefficient of 0.6. Azwar (2017) explained that $V$ values higher than 0.5 indicated good content validity. The career planning guidebook had good content validity using this criterion. According to the expert judges, some of the main advantages of the career planning guidebook were the communicative language, simple and systematic flow, and the availability of worksheets, which captured most of the career planning process phases. Overall, from the aspect of content validity, the expert judges showed that the career planning guidebook was of good quality.

Concerning functional validity, the quasi-experiment using the one group pretest and posttest design (Figure 2) showed that the subjects' perception of their career planning had increased following engagement with the career planning guidebook. In the career planning guidebook, knowledge was given about career planning, but worksheets were also available to put the knowledge into practice. 
For the material on self-analyses, the subject was required to reflect upon their characteristics, strengths and weaknesses, work interests, and ambitions or dreams. The material allowed the subjects to have a better understanding of themselves. This process was important because selfunderstanding is one of the important steppingstones for career planning. This is in line with Tarigan and Wimbarti (2011), who suggested that the fundamental elements of career planning and selfunderstanding consist of self-evaluation, understanding personal values, weaknesses and strengths, and awareness of their potential. When individuals can identify their ambitions and career interests clearly, and understand their strengths and weaknesses, it would be easier for them to seek the correct career information.

Seeking information is an important part of stage 2 in the career planning process, namely exploring opportunities. In the career planning guidebook, subjects are asked to seek information about a range of careers and qualifications that are needed in that field. By seeking information related to a career, it is expected to broaden a person's career perspectives. Chan (2017) explained that career exploration (for example seeking information on work types) was crucial in choosing a career.

In the material of goal setting and career planning, the subject was asked to start making career decisions, which would become the basis of the goals they formulate. This is important because when a person has a clear goal, they would cognitively be motivated to act persistently in the right direction (Tarigan \& Wimbarti, 2011). In determining the career choice (goals), the subjects were asked to consider supporting factors and obstacles in achieving those goals, coming from within and beyond the individual. By identifying the obstacles, the individual is psychologically more prepared to make a career decision. At this stage, the career choice is made after the individuals engage in selfexploration (stage 1 self-analysis) and environmental exploration (stage 2 seek career information). Hirschi, Niles, and Akos (2011) suggested that self-exploration and environmental exploration were positively associated with increases in an individuals' capacity to make career choices. This is also consistent with Chan (2017), who mentioned that career exploration was positively associated with career choice. Career exploration increases abilities in career planning and the decision making associated with career choice. By gathering information, for example, work types, individual can make better career decisions. Individuals would know how their field of study aligns with the particular jobs that interest them, which all are taken into account when making a career decision. After the subject makes their career choice on the goal setting and career planning material, they are asked to make a plan of action to achieve the goal (career choice) and make an alternative career plan.

In the material of implementation or action plan, the subject is given perspective about the importance of an action plan in the form of daily or weekly activities relevant to the goal. The plan of action is different from the plan of goal setting and career planning. For the goalsetting plan, the plan was made as a general vision, while in the implementation phase, the plans are more detailed and specific. By making a detailed plan, the subject should be more able to manage their activities. Career planning has been shown to positively associate with career- 
related self-regulation behaviors (Vos, Clippeleer, \& Dewilde, 2009), career management, and career development (Adekola, 2011).

The final stage of career planning is the evaluation of results. In this section, the subjects understand the importance of evaluating the plan of action. Furthermore, the subjects are asked to evaluate achievements in the career planning stage on the available worksheets. This activity allows the subject to reflect on the process of achieving the career plan. The subject can conclude which career choice is most appropriate.

The difference between the career plan guidebook with other career interventions is the reading, understanding, and completing worksheets, which are all done by an individual without the help of another person. These independent activities can make the subject motivated and responsible in making their career plans. The subjects are involved in developing their insights. Most of the subjects mentioned that after reading and completing the worksheets, they were more informed of their strengths and weaknesses, they understood their field of work and knew what strategy to achieve the desired career. One of the subjects mentioned that after completing the book, she/he could decide his/her career. Other subjects mentioned that they already knew their career choice in psychology, and they were certain in their career choice.

Based on the tests of content validity and functional validity, the results showed that the career planning guidebook based on Jaffe and Scott (1991) had sufficient validity and can be used for further research related to career planning. In the current study, there were two primary limitations. The first limitation relates to the experimental research design and measures. First, there was only one experimental group in this study, namely the experimental group, and we did not use a control group. The absence of a control group is allowed, as mentioned by Azwar (2017); however, with a control group, the treatment's effectiveness can be established with more confidence (Shadish et al., 2002). Second, the career planning scale used was an individual's perception of their ability to make a career plan. The researcher did not measure the level of understanding and skills of career planning, which was acquired by the subject. Had these also been measured, this would have made the research more comprehensive since the career planning guidebook contains explanations about career planning and worksheets to increase knowledge and skills in career planning.

\section{Conclusion}

Based on the research results, we can conclude that the career planning guidebook was valid in both content and functional aspects. The career planning guidebook has content validity and is proven by tests of each topic (sub-section), which produced $V$ coefficients ranging from $0.525-0.675$ and an overall content validity coefficient of 0.6 . The analyses of functional validity using the Wilcoxon signed-rank test showed $Z=-3.987, p=0.000$ $(p<0.01)$. This means that there was difference in career planning perceptions before and after completing the guidebook. The subjects felt that they were more able to plan their careers after completing the career planning guidebook.

\section{Suggestion}

For the researcher interested in investigating the validity of the career planning 
guidebook, they can optimize the current research by modifying the research design from a pretest-posttest control group design and use a more comprehensive set of measures. For example, not only measuring perceptions but actual knowledge and skills.

\section{Acknowledgement}

The authors would like to thank the Institute for Research and Development of Universitas Ahmad Dahlan (LPP UAD) who had funded this research, the Dean of the Faculty of Psychology UAD that had given permission to conduct this research in the faculty of Psychology UAD, and all the students and researchers that spared their time to participate in this research project.

\section{Funding}

This research was funded by the Institute of Research and Development Universitas Ahmad Dahlan (LPPM UAD) Contract Number: PF-061/SP3/LPP-UAD/IV/2018

\section{Author's contribution}

Dian Kinayung designed the research, managed the research, conducted the data analyses, discussion and wrote the manuscript. Difa Ardiyanti contributed in creating the module, measures, analyzing the data, and also writing the manuscript.

\section{Conflict of interest}

The authors state that there is no conflict of interest in this research.

\section{Orcid id}

https://orcid.org/0000-0002-2299-0012

\section{References}

Adekola, B. (2011). Career planning and career management as correlates for career development and job satisfaction a case study of Nigerian bank employees.
Australian Journal of Business and Management Research, 1(2), 100-112.

Amundson, N. E., Borgen, W. A., Iaquinta, M., Butterfield, L. D., \& Koert, E. (2010). Career decision from the decider's perspective. The Career Development Quarterly, 58(4), 336351. doi: 10.1002/j.21610045.2010.tb00182.x

Ardiyanti, D. \& Alsa, A. (2015). Pelatihan "PLANS" untuk meningkatkan efikasi diri dalam pengambilan keputusan karier. Gadjah Mada Journal of Professional Psychology (GamaJPP), 1(1), 1-17.

Azwar, S. (2017). Metode penelitian psikologi edisi II. Yogyakarta: Pustaka Pelajar.

Chen, S. \& Zhou, K. (2018). Career planning decision-making of college students based on cognitive science. NeuroQuantology, 16(6), 487-493. doi: 10.14704/nq.2018.16.6.1662

Chan, C.-C. (2017). The relationship among social support, career selfefficacy, career exploration, and career choices of Taiwanese college athletes. Journal of Hospitality, Leisure, Sport $\mathcal{E}$ Tourism Education, 22, 105-109. doi: 10.1016/j.jhlste.2017.09.004

Fouad, N., Cotter, E.W., \& Kantamneni, N. (2009). The effectiveness of a career decision-making course. Journal of Career Assessment, 17(3), 338-347. doi: $10.1177 / 1069072708330678$

Germeijs, V., \& Verschueren, K,. \& Soenens, B. (2006). Indeciveness and high school students career decision-making process: Longitudinal association and the meditational role of anxiety. Journal of Counseling Psychology, 53(4), 397410. 
Hanggara, G. S. (2016). Keefektifan "proses guru" sebagai teknik bimbingan kelompok untuk meningkatkan kemampuan pengambilan keputusan karier siswa SMK. Jurnal Kajian Bimbingan dan Konseling, 1(4), 148-157.

Hidayat, M. \& Alsa, A. (2018). The effect of "PLANS" training towards career maturity of senior high school students. Journal of Educational, Health and Community Psychology, 7(2), 160-178. doi: 10.12928/jehcp.v7i2.9681

Hirschi, A., Niles, S. G., \& Akos, P. (2011). Engagement in adolescent career preparation: Social support, personality and the development of choice decidedness and congruence. Journal of Adolescence, 34(1), 173-182. doi: 10.1016/j.adolescence.2009.12.009

Iffah, F. N. (2012). Pelatihan efikasi diri untuk meningkatkan kemampuan pengambilan keputusan karier siswa SMA. (Unpublished master thesis). Faculty of Psychology Universitas Muhammadiyah Surakarta, Surakarta.

Jaffe, D. T., \& Scott, C. D. (1991). Career development for empowerment in a changing work world. Dalam Kummerow, J. M. (Ed), New directions in carrer planning (hlm. 3359). California: CPP Books.

Kustanani, E. R. (2010). Efektifitas pelatihan "Lebih Dekat dengan Masa Depanku" untuk menggapai kematangan vokasional siswa SMP. (Unpublished master thesis). Faculty of Psychology Universitas Gadjah Mada, Yogyakarta.

Kusumaningrum, D. S. (2012). Pengaruh workshop bimbingan karier terhadap efikasi diri dalam pengambilan keputusan karier. (Unpublished master thesis). Faculty of Psychology Universitas Gadjah Mada, Yogyakarta.

Lam, M. \& Santos, A. (2017). The impact of a college career intervention program on career decision selfefficacy, career indecision, and decision-making difficulties. Journal of Career Assessment, 26(3), 425-444.

doi:

$\underline{10.1177 / 1069072717714539}$

Lestari, R. T. (2010). Peran Konseling Karier "Bersama Menggapai Cita" dalam meningkatkan keterampilan penetapan keputusan karier pada siswa perempuan SMA. (Unpublished master thesis). Faculty of Psychology Universitas Gadjah Mada, Yogyakarta.

Mulyana, O. P. (2009). Peningkatan efikasi diri terhadap pengambilan keputusan karier melalui pelatihan perencanaan karier. (Unpublished master thesis). Faculty of Psychology Universitas Gadjah Mada, Yogyakarta.

Praskova, A., Creed, P. A., \& Hood, M. (2015). Career identity and the complex mediating relationships between career preparatory actions and career progress markers. Journal of Vocational Behavior, 87, 145-153.

doi: 10.1016/j.jvb.2015.01.001

Sangganjanavanich, V.F., \& Magnuson, S. (2011). Using sand trays and miniature figures to facilitate career decision making. The Career Development Quarterly, 59(3), 264273.

doi: 10.1002/j.21610045.2011.tb00068.x

Sawitri, D. R. (2009). Pengaruh status identitas dan efikasi diri keputusan karier terhadap keraguan mengambil keputusan karier pada mahasiswa tahun pertama di 
universitas diponegoro. Jurnal Psikologi Undip, 5(2), 1-14.

Shadish, W.R, Cook, T.D., Campbell, D.T. (2002). Experimental and quasiexperimental design for generalized causal inference. New York: Houghton Mifflin Company.

Syahraini. (2012). Pelatihan "Menemukan Langkah Terbaikku" untuk meningkatkan keterampilan pengambilan keputusan karier pada siswa MAN. (Unpublished master thesis). Faculty of Psychology Universitas Gadjah Mada, Yogyakarta.

Super, D.E. (1980). A life-span, life-space approach to career development. Journal of Vocational Behavior, 16(3), 282-298. doi: 10.1016/00018791(80)90056-1

Talib, J. A., Salleh, A., Amat, S., Ghavifekr, S., \& Ariff, A. M. (2014). Effect of career education module on career development of community college students. International Journal of Educational and Vocational Guidance, 15(1), 37-55. doi: 10.1007/s10775-014-9279-x

Talib, J. B. A., Mohamad, Z., Wahab, N. A. (2015). Effects of career exploration module on career planning, career self-efficacy and career maturity among community college students. Mediterranean Journal of Social Sciences, 6(6), 464-469. doi: 10.5901/mjss.2015.v6n6s1p464
Tarigan, M. \& Wimbarti, S., (2011). Career planning program to increase career search self efficacy in fresh graduates. Journal of Higher Education Theory and Practice, 11(4), 75-87.

Teychenne, M., Parker, K., Teychenne, D., Sahlqvist, S., Macfarlane, S., \& Costigan, S. (2019). A pre-post evaluation of an online career planning module on university students' career adaptability. Journal of Teaching and Learning for Graduate Employability, 10(1), 42-55. doi:

10.21153/jtlge2019vol10no1art781

Vos, A. D., Clippeleer, I. D., \& Dewilde, T. (2009). Proactive career behaviours and career success during the early career. Journal of Occupational and Organizational Psychology, 82(4), 761-777. doi: $\underline{10.1348 / 096317909 X 471013}$

Wang, J., Zhang, D., \& Shao, J. (2010). Group Training on the improvement of college student's career decision-making selfefficacy. Health, 2(6), 551-556. doi: 10.4236/health.2010.26082

Yollanda, M. (2017). Hubungan antara self esteem dan dukungan sosial keluarga dengan optimisme meraih kesuksesan karier pada mahasiswa. (Unpublished undergraduate thesis). Faculty of Psychology Universitas Ahmad Dahlan, Yogyakarta 